\title{
An Eighteenth Dynasty writing board (Ashmolean 1948.91) and The Hymn to the Nile
}

Hagen, Frederik Norland

Published in:

Journal of the American Research Center in Egypt

Publication date:

2013

Document version

Publisher's PDF, also known as Version of record

Citation for published version (APA):

Hagen, F. N. (2013). An Eighteenth Dynasty writing board (Ashmolean 1948.91) and The Hymn to the Nile. Journal of the American Research Center in Egypt, 49(1), 73-91. 


\title{
An Eighteenth Dynasty Writing Board (Ashmolean 1948.91) and The Hymn to the Nile
}

\author{
FREDRIK HAGEN
}

\begin{abstract}
The article presents a writing tablet from the Ashmolean Museum, Oxford. It contains various administrative accounts as well as one of the earliest-known copies, in duplicate, of the initial lines of The Hymn to the Nile, written by different hands, probably made by a teacher and his student. The variants of the two copies are compared and analysed, and the use of writing boards in New Kingdom Egypt is outlined. Finally, the social context of the hymn is discussed.
\end{abstract}

Introduction

Ashmolean writing tablet 1948.91 (figs. 1-4) $)^{1}$ is a wooden board roughly fourteen cm wide and twenty-five cm long, wrapped in linen (which is now clearly visible in the bottom left hand corner of the verso), and covered in stucco (originally bright white in color, this has now become brown with age) and with a hole for a suspension cord on the left-hand side. ${ }^{2}$ Despite its modest size, the tablet is a fine example of a New Kingdom writing board and is almost perfectly preserved. The front has three lines of hieratic from the beginning of the well-known literary text The Hymn to the Nile, as well as two columns of an account mentioning various individuals and quantities of cloth, and detailed drawings of two grasshoppers as well as a falcon's head with a sun on top. The literary text has versepoints in red ink, as well as a number in red (presumably referring to a date) following the final line. The back has the same passage of The Hymn to the Nile, in a different hand to the front and without versepoints. Both sides contain traces of palimpsest. The object was given to the Ashmolean Museum by Sir Alan H. Gardiner in 1948, and the museum records list its provenance as "Thebes, Egypt (Qurna)," but there is no further information about the precise archaeological circumstances of its discovery, and how Gardiner acquired it remains unknown. He made a preliminary transcription while it was still in his possession (in his notes he refers to it by his own numbering system in which it was designated "62.8"), and this is now kept in the Griffith Institute, Oxford. ${ }^{3}$ The writing board has occasionally been referred to in Egyptological literature, and the literary text has been included in synoptic text editions, one of which also provided black and white photographs of the front and the back. ${ }^{4}$ However, it has never been fully

${ }^{1}$ I am grateful to Susan Walker, Keeper of Antiquities in the Ashmolean Museum, for permission to publish the object, and for providing photographs of it. Xavier Droux very kindly assisted me during my visit to examine the writing board in May 2010.

${ }_{2}^{2}$ The photographs included here (figs. 1-2) show the writing board as currently preserved. The synoptic edition of The Hymn to the Nile (see n. 4 below) contains photographs taken in the 1950s or 1960s when the tablet was in a better shape than it is now: this is particularly evident around the edges and is mostly due to some of the stucco subsequently having broken up and fallen off. It has since been stabilized by conservators and does not appear to deteriorating further.

${ }^{3}$ MSS AHG 29.34a-b. I am grateful to Elizabeth Flemming of the Griffith Institute for her help in consulting Gardiner's notes, which included a transcription of the second column of the account (but not the traces of the first).

${ }^{4}$ D. van der Plas, L'Hymne á la crue du Nil (Leiden, 1986), pls. 6-7; W. Helck, Der Text des "Nilhymnus" (Wiesbaden, 1972); cf. 


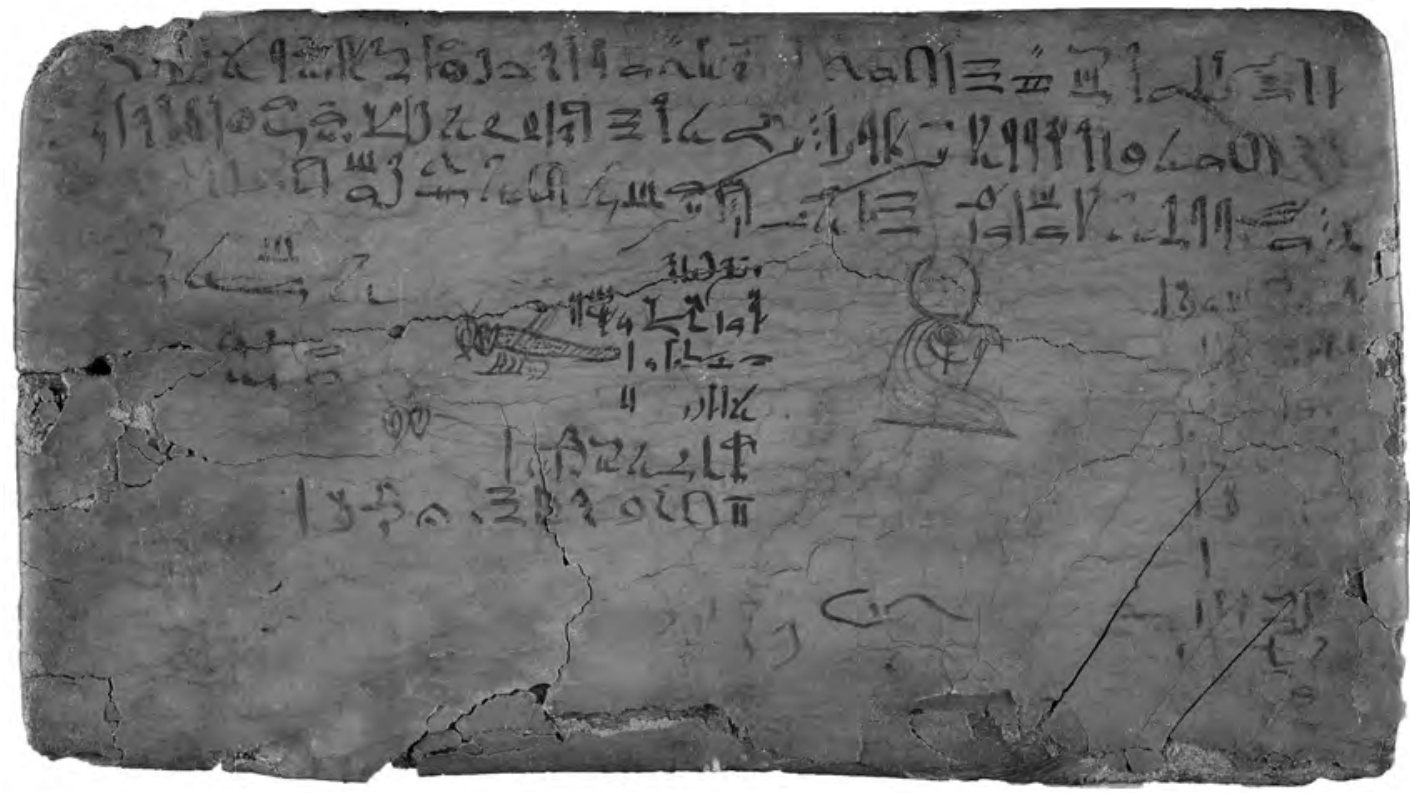

Fig. 1. Ashmolean 1948.91 (recto). Photograph courtesy of the Ashmolean Museum, Oxford.

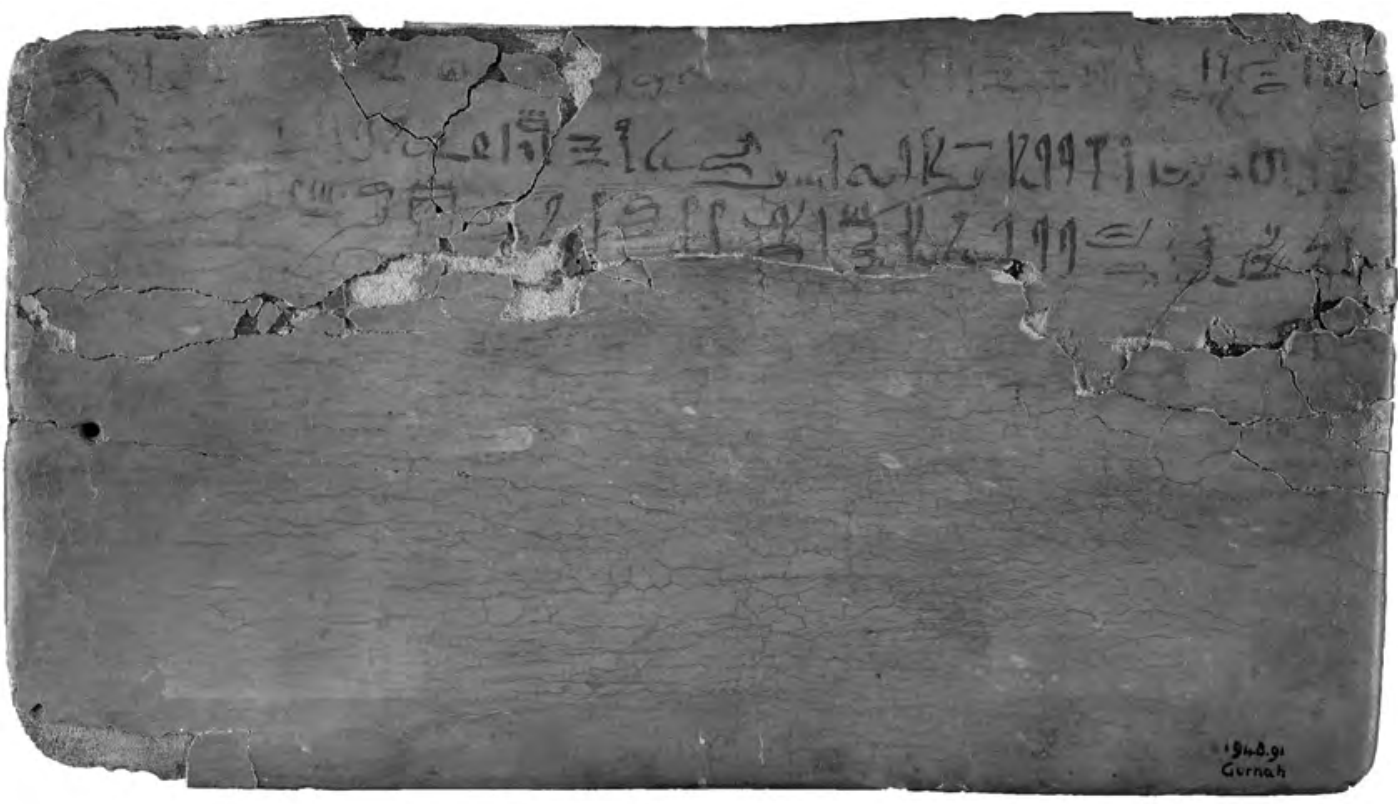

Fig. 2. Ashmolean 1948.91 (verso). Photograph courtesy of the Ashmolean Museum, Oxford. 


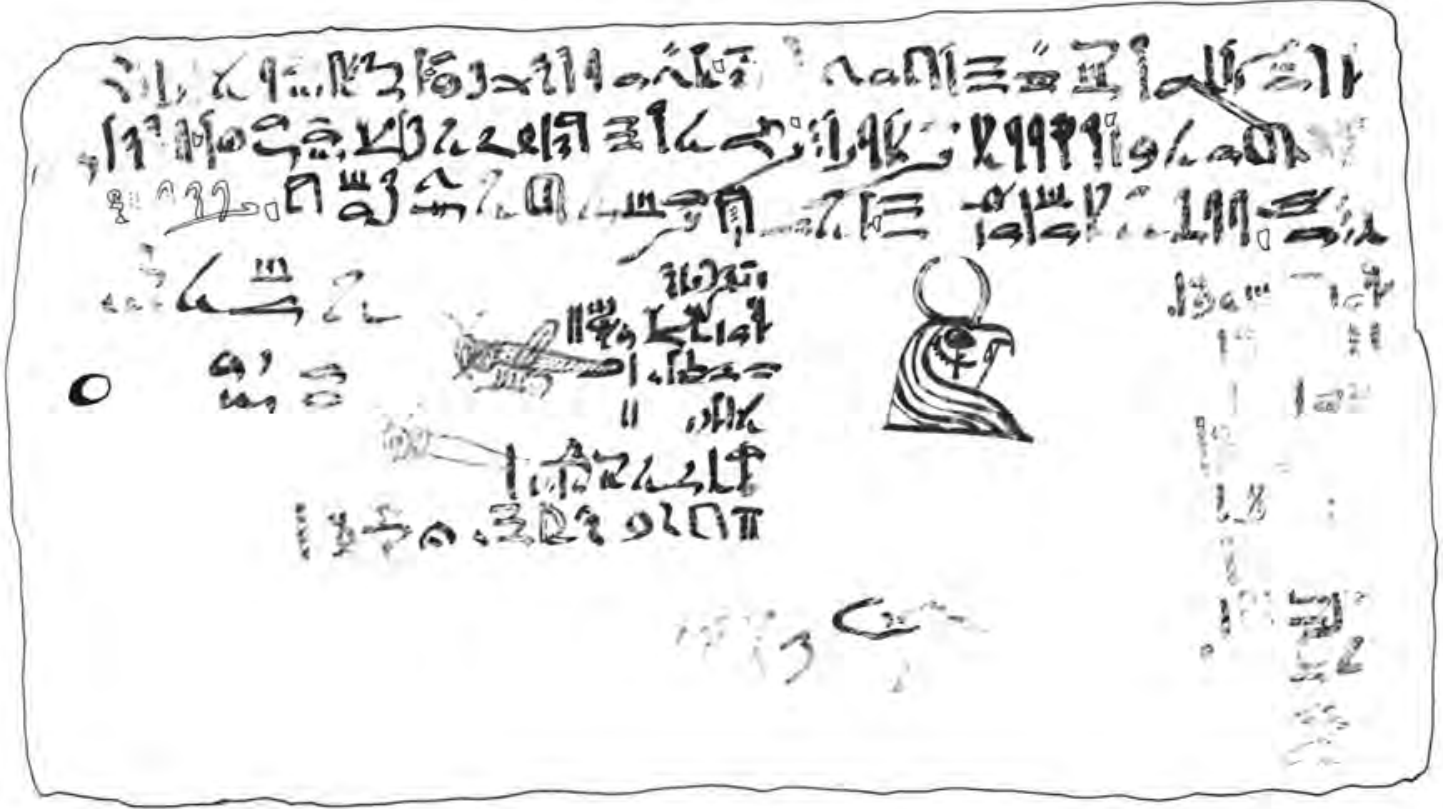

Fig. 3a. Facsimile drawing of Ashmolean 1948.91 (recto) by F. Hagen.

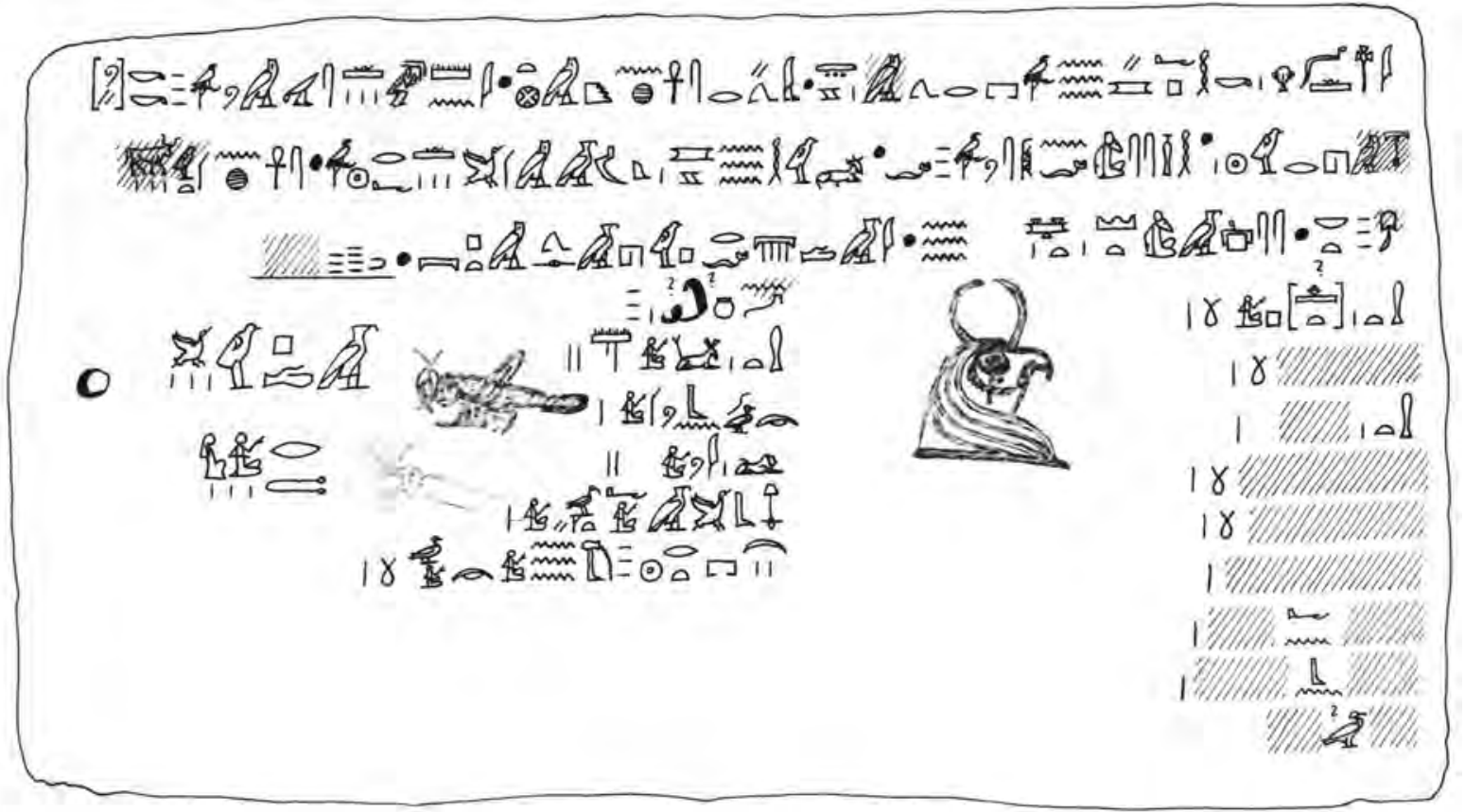

Fig. 3b. Hieroglyphic transcription of Ashmolean 1948.91 (recto) by F. Hagen. 


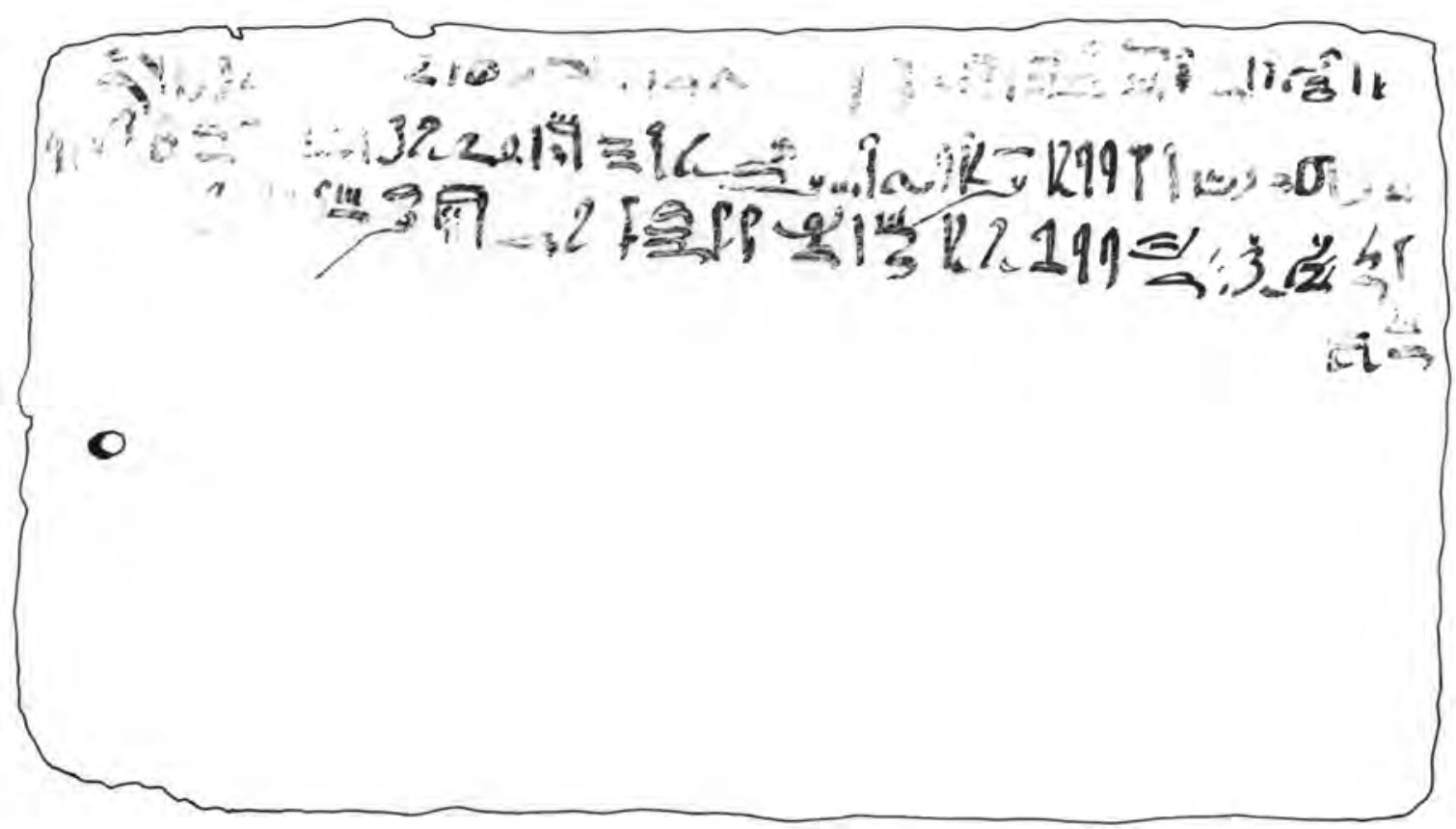

Fig. 4a. Facsimile drawing of Ashmolean 1948.91 (verso) by F. Hagen.

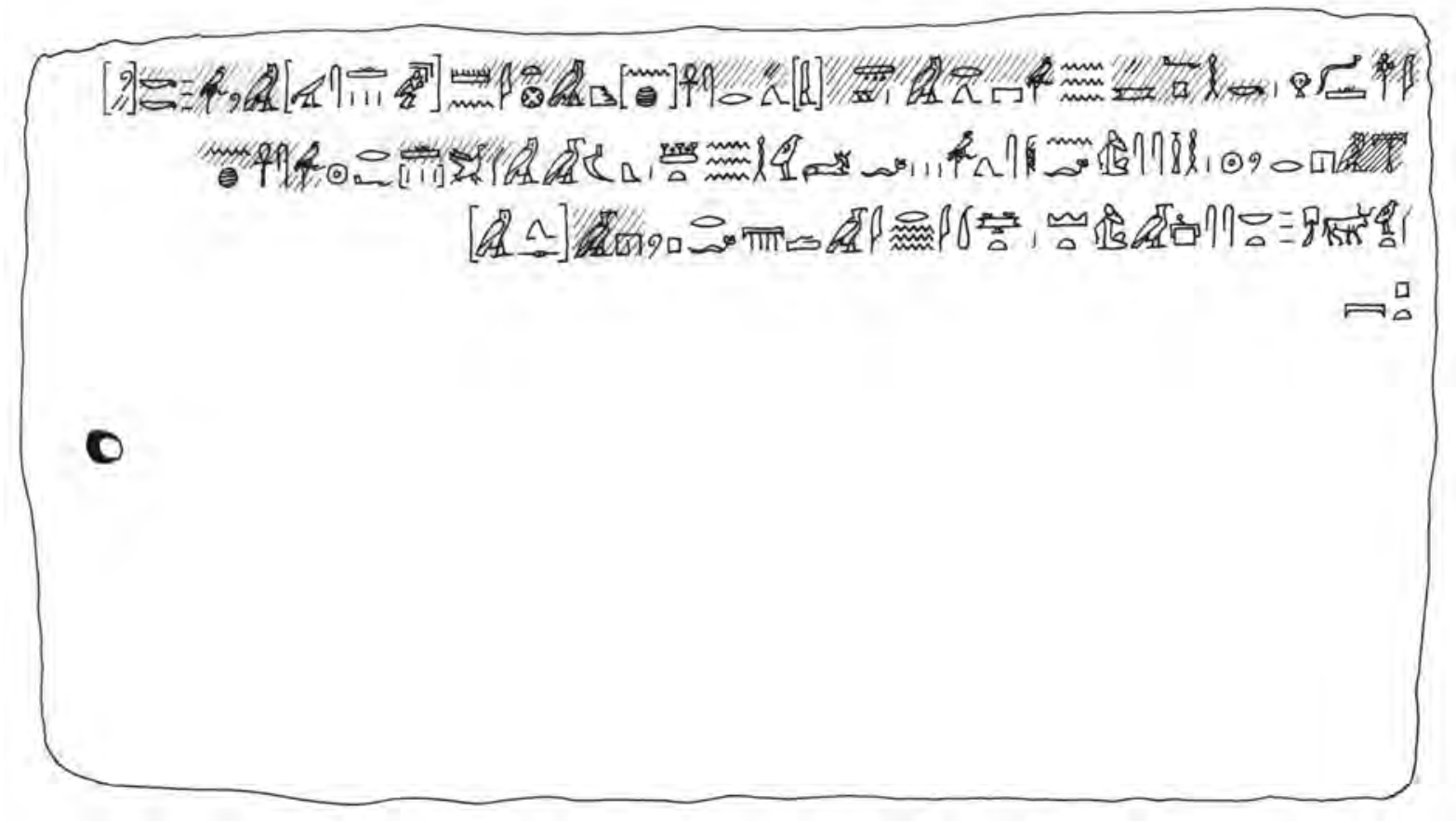

Fig. 4b. Hieroglyphic transcription of Ashmolean 1948.91 (verso) by F. Hagen. 
published: the administrative text has never been transcribed or translated, the relationship between the two parallel copies of the same passage of the same literary text has never been examined, and the published transcriptions of the latter have excluded the majority of the red versepoints as well as the date following the text on the recto. In this article I present and analyze these aspects in order to relate the object to its social context, an exercise that takes its inspiration from the school of Material (or "New") Philology as pioneered in European Renaissance studies. ${ }^{5}$ This follows recent developments within Egyptological philology where there has been a partial shift away from the "old" philological obsession with stemmata, scribal mistakes, and the reconstruction of that unicorn of philology, the mythical Ur-text, towards a new set of research objectives that focus on social context, on textual tradition as a continuum of variance and fluidity, and on literary manuscripts as part of a broader material culture and practice. ${ }^{6}$

\section{Palaeography and Orthography}

The designations "recto" and "verso" as employed by previous commentators are largely arbitrary and serve as a means of identification for the two sides, wholly separated from any consideration of which was written first (and therefore presumably served as the model for the other), but they are retained here for convenience. The comparably poor survival of the ink on the "verso" combined with the brevity of the extract makes a comparison of the hieratic hand (hereafter hand "V") with that of the "recto" (hereafter hand "R") difficult, and only a few observations are possible. Firstly, it is clear that the hands are similar but not identical, a fact that may be accounted for partly by the similarity in date and perhaps also by the possibly close relationship between the writers (if they were indeed student and teacher). Secondly, hand R seems more careful, more deliberate, and perhaps more concerned with aesthetic appearance than hand V. ${ }^{7}$ Thirdly, despite the superior aesthetics of $\mathrm{R}, \mathrm{V}$ has a more correct text. ${ }^{8}$

The differences in orthography between $\mathrm{R}$ and $\mathrm{V}$ are generally small and inconsequential for the legibility of the text, ${ }^{9}$ but one example provides a singular clue as to the sequence in which the texts on the "recto" and "verso" were written. Whereas V included the signs $0\{$ in the writing of $w 3 . t i$, "be far from" in line three, the scribe who wrote the "recto" text simply left a blank space where this ending would have gone. It seems plausible to conclude from this that the "verso" was in fact written first, and that the scribe who wrote the "recto" paused upon encountering the unfamiliar stative ending, left the corresponding space blank, and continued writing. If one applies the "teacher-student" paradigm to this data-and this would be in line with the date in red discussed below-two points appear significant to

H. Brunner, Altägyptische Erziehung (Wiesbaden, 1957), fig. 6 (photo, front); L. Cottrell, Life under the Pharaohs (London, 1955), pl. 34 (photo, front).

${ }^{5}$ For a brief introduction to New or Material Philology, with bibliography, see F. Hagen, An Ancient Egyptian Literary Text in Context: The Instruction of Ptahhotep, OLA 218 (Leuven, 2012), 26-28.

${ }^{6}$ Programmatically by R. Parkinson, "The History of a Poem: Middle Kingdom Literary Manuscripts and their Reception," in G. Burkard, ed., Kon-Texte: Akten des Symposions "Spurensuche - Altägypten im Spiegel seiner Texte", München 2. Bis 4. Mai 2003, ÄAT 60 (Wiesbaden, 2004), 51-63; compare also idem, Reading Ancient Egyptian Poetry (Oxford, 2009), 272-78.

${ }_{7}$ This impression finds some support in the attempt by $\mathrm{R}$ to avoid ligatures whereas $\mathrm{V}$ makes few such attempts: compare the writing of $\frac{U}{a}$ in line three, but note R's use of a ligatured $\frac{\theta}{\theta}$ in $1 f \frac{\theta}{\theta}$, in lines one and two (the corresponding passages of the latter are lost on the verso). $\mathrm{R}$ also sometimes has more detailed hieratic forms than $\mathrm{V}$ : compare the use the full form $(\mathrm{R})$ rather than the abbreviated $@(\mathrm{~V})$ in lines two and three. Not all forms are simplified by $\mathrm{V}$, however, and occasionally it even exhibits more complex forms than $\mathrm{R}$, although all examples concern details of the signs that cannot be said to be comparable to the ligatures mentioned above: compare $\overline{\pi T}$ in line three (where $\mathrm{R}$ has a single middle column of water to V's two).

${ }^{8} \mathrm{Cf}$. the writing $\cong$ by V in line three, where R left out the preposition $\rightleftharpoons$, probably erroneously (the expression is $w^{3} r N$, "to be far from N."; $\overline{c f}$. Wb. I, 245.5-6). The feminine stative ending 0 \{ in 0 \} in V (line three) is also more correct than the simple in R.

${ }^{9} \mathrm{R}$ substitutes V's determinative $\boldsymbol{\Lambda}$ in šmsw, "followers" (line two) for the plural ending @; V leaves out the stroke determinative in 
me: (1) the student (R) has a more considered and careful handwriting than the teacher (V), and (2) the teacher, not surprisingly, wrote a text that was more grammatically correct than the student's.

The only criterion available for dating the writing board is the handwriting. The earliest commentators thought the most plausible date to be sometime in the first half of the Eighteenth Dynasty, ${ }^{10}$ but others have assumed a later date in the early Ramesside Period, ${ }^{11}$ although no palaeographical analysis has ever been presented. The shortness of the extant text limits the exactness of palaeographical dating, but, partly based on the list of "diagnostic" signs for dating Eighteenth Dynasty literary manuscripts drawn up by G. Möller, ${ }^{12}$ the following forms would seem to confirm a pre-Ramesside date:

(Gardiner E1): The unusually detailed form is certainly pre-Ramesside, and close to other early Eighteenth Dynasty or even SIP manuscripts: ${ }^{13}$

(Gardiner E9): Of the examples listed by Möller, this is closest to Papyrus Westcar: ${ }^{14}$;

$\mathcal{L}$ (Gardiner Aa17): The most diagnostic feature in comparison with later forms is the pronounced horizontal line at the bottom which disappears in Ramesside manuscripts; the absence of the tick on the right is noteworthy but hardly decisive for dating purposes: ${ }^{15} 1,1$

(Gardiner F27): The form is wholly different from Ramesside examples, but it is very close to Papyrus Westcar and Papyrus Ebers: ${ }^{16} \boldsymbol{\mathcal { L }}, \mathfrak{j}$

$\pi \mathrm{Tr}$ (Gardiner N4): Although a rare sign with little data for comparison in terms of its form, its inclusion here is itself significant because Ramesside manuscripts of the same text use the generic determinative for sky ( other Ramesside hieratic manuscripts where the word 33 d.t, "dew," occurs: ${ }^{17}$ 南, 宸

(Gardiner T18): The sign is definitely pre-Ramesside in form, with the closest parallels being Papyrus Westcar and Papyrus Ebers: ${ }^{18} \hat{k}, \mathbb{K}$

3 (Gardiner M18): The form echoes other early Eighteenth Dynasty manuscripts: ${ }^{19} \mathfrak{k}$

I (Gardiner W14): The separate diagonal stroke under the top of the sign is typical of manuscripts from the Middle Kingdom up to the early Eighteenth Dynasty: ${ }^{20} \mathbf{q}, \mathbf{P}$

${ }^{10}$ This date was initially suggested by Gardiner himself; Gardiner, EG, 20, n. 11 (“early Dyn. XVIII”); cf. J. Quack, Studien zur Lehre für Merikare, GOF IV.23 (Harrassowitz, 1992), 134; idem, "Irrungen, Wirrungen? Forscherische Ansätze zur Datierung der älteren ägyptischen Literatur," in G. Moers, et al, eds., Dating Egyptian Texts, Lingua Aegyptia Studia Monographica 11 (Hamburg, 2013), 426.

${ }^{11}$ W. Helck, Der Text des "Nilhymnus", 86, claimed that no manuscripts of the text older than the Nineteenth Dynasty survives, implicitly dating the Ashmolean tablet to the Nineteenth Dynasty at the earliest; this dating was accepted by van der Plas, L'Hymne á la crue du Nil, 11.

${ }_{12}$ G. Möller, "Zur Datierung literarischer Handschriften aus der ersten Hälfte des Neuen Reichs," Z̈̈S 56 (1920), 34, pls. 1-3.

${ }^{13}$ Recto line 2 (damaged); verso line 3; cf. Möller, Paläographie I, 13; II, 12; no. 142. The sign was transcribed as (E8) and (E28) by van der Plas, L'Hymne á la crue du Nil, vol. II, 13, 162.

${ }_{14}$ Recto line 2, verso line 2; cf. Möller, Paläographie, I, 13; II, 12; no. 143.

${ }^{15}$ Recto line three, verso line three; Möller, Paläographie, I., 57; II, 53; no. 587; Möller, "Zur Datierung literarischer Handschriften," pl. 3.

${ }^{16}$ Recto line three (damaged), verso line three; Möller, Hieratische Paläographie, vol. I, 15; vol. II, 14; no. 166; Möller, "Zur Datierung literarischer Handschriften," pl. 2.

${ }_{17}$ Van der Plas, L'Hymne á la crue du Nil, vol II, 15; cf. Wb. I, 36; the only exceptions are Book of the Dead manuscripts with cursive hieroglyphs.

${ }^{18}$ Recto line two, verso line two; Möller, Paläographie, I, 42; II, 39; no. 443.

${ }_{19}$ Recto line one; Möller, Paläographie, I, 27; II, 26; no. 284.

${ }^{20}$ Clear in line two of the recto, less so on the verso; Möller, Paläographie, I, 47; II, 45; no. 502 
Less indicative but perhaps noteworthy is the restrained form of $1 .{ }^{21}$ and the orthography of the name Hapy (here $\rightarrow 1 \rightarrow{ }^{2}$

I have elsewhere drawn attention to some of the problems associated with the dating of administrative documents using palaeography, ${ }^{23}$ and the situation is if anything more precarious when dealing with literary manuscripts, especially from the first half of the Eighteenth Dynasty because few examples of this date were included in the standard palaeographies. ${ }^{24}$ Nonetheless, a date in the early Eighteenth Dynasty should be uncontroversial in view of the arguments outlined above, and it is my impression that it should be dated to the very beginning of that period, but the lack of securely dated comparative data makes it impossible to narrow the range any further. The date of the manuscript is important because it appears to be one of the earliest known copies of the hymn, ${ }^{25}$ and it goes to the heart of the vexed question of the composition date of the text itself. Establishing the composition date of The Hymn to the Nile falls outside the scope of this article, but it is worth noting that much of the circumstantial evidence used by van der Plas to argue for a date in the early New Kingdom (" $18^{\mathrm{e}}-19^{\mathrm{e}}$ dyn.")-largely concerned with zeitgeist-postdates the Ashmolean tablet and so cannot be used in the way he proposes. ${ }^{26}$ That is not to say that the text was composed in the Middle Kingdom, and anyone wanting to argue for an early date would have to account for linguistic constructions that are traditionally seen as post-Middle Kingdom in date..$^{27}$

\section{Versepoints and Date in Red}

Only the "recto" of the tablet carries versepoints in red ink. These invariably occur at the end of semantic and syntactic units ("verses"), but unlike most other literary manuscripts they are found low down between the hieratic signs rather than above them. The text on the "recto" has a date in red ink following the final signs of the Hymn to the Nile, reading "(day) 17." Such dates are often associated with scribal exercises, ${ }^{28}$ but they also appear in literary manuscripts that are not generally regarded as

${ }^{21}$ Recto lines two and three; verso lines two and three; somewhat abbreviated and unusually narrow form.

${ }_{22}$ Generally written 8 (i.e., with the determinatives Ramesside manuscripts, with some notable exceptions, e.g., the Great Harris Papyrus; cf. P. Grandet, Le Papyrus Harris I, BdÉ 129 (Cairo, 1999), vol. 3, 245.

${ }^{23}$ F. Hagen, “A Ramesside Administrative Document (P. Cambridge University Library MS. Add. 4167)," Z̈̈S 135 (2008), $31-33$.

${ }^{24}$ Cf. the comments by Möller, "Zur Datierung literarischer Handschriften," 34.

${ }_{25}$ The recently discovered literary graffiti in tomb N13.1 at Assiut include passages from The Hymn to the Nile (§§I.1-V.8; VIII.1-8; IX.1-XIV.7), and although they have yet to be published, it seems clear that they too date to the early Eighteenth Dynasty (U. Verhoeven, pers. comm). For the first of these, see U. Verhoeven, "The New Kingdom Graffiti in Tomb N13.1: An Overview," in J. Kahl, et al, eds., Seven Seasons at Asyut (Wiesbaden, 2012), 47-58.

${ }^{26}$ Van der Plas, L'Hymne á la crue du Nil, I, 187-90. Just as this article was going to press, an article by Van der Plas dealing with the dating of the Hymn to the Nile appeared, D. van der Plas, "Dating the Hymn to Hapi. An Update of the Late Date," in G. Moers, et al, eds., Dating Egyptian Literary Texts, 471-82. Due to its late appearance I cannot make full use of it here, but I note that he reiterates his position in regard to composition date, with the important modification that he narrows down the range to the early Eighteenth Dynasty in view of the surviving manuscript tradition, and withdraws the suggested link with the ideology of the Amarna period. His arguments primarily relate to "the formal structure and content" (§4), "theological concepts" (§5), "linguistic facts" (§6), "Date according to the author" (\$7), and "royal propaganda: religion and politics" (§8).

${ }^{27}$ See, e.g., the two "Late-Egyptianisms" in §IV.7 ( $\left.s w m d w 3 . t\right)$ and $\S V I .4$ ( $\left.t w n \underline{d} h r t=f m n s w\right)$, as well as other elements. I refrain from a discussion of the linguistic evidence here; a thorough analysis of these passages in the context of a general discussion about the use of such data for dating purposes can be found in A. Stauder, Linguistic Dating of Middle Egyptian Literary Texts, Lingua Aegyptia Studia Monographica 12 (Hamburg, 2013), 215-36; he suggests a composition date no earlier than the late Seventeenth Dynasty, but more probably sometime in the early Eighteenth Dynasty (i.e., not much earlier than the first manuscripts). I am grateful to him for discussing the issues with me, and for letting me read a preliminary version of his book.

28 A. McDowell, "Student Exercises from Deir el-Medina: The Dates," in P. der Manuelian, ed., Studies in Honor of William Kelly Simpson (Boston, 1996), 601-8. 
student exercises ${ }^{29}$ so they should not, on their own, be considered a diagnostic feature for the identification of an exercise. However, in the case of Ashmolean 1948.91, the presence of both versepoints and a date on the "recto" conforms to the student/teacher paradigm suggested by other evidence, as outlined above.

\section{Transcription and Translation}

The transcription (figs. $3 \mathrm{~b}$ and $4 \mathrm{~b}$ ) is based on close examination of the original and occasionally differs from the one published by van der Plas. It includes all the text on the board that is legible today, but for the sake of brevity I translate only the recto (the version on the verso has no significant semantic variants), and I provide little philological commentary for the literary text; readers should consult the synoptic edition by van der Plas for discussions of problematic passages in The Hymn to the Nile. All names in the administrative text can be found in Hermann Ranke's Die ägyptische Personennamen (Glückstadt, 1935) unless otherwise noted in the commentary.

\section{Recto}

(1) Hail to you, Hapy, who comes forth from the earth,

who arrives in order to give Egypt life,

whose nature is hidden, (as) darkness during (2) the day,

to whom his followers sing,

who inundates the fields created by $\mathrm{Re},{ }^{30} \bullet$

who makes every herd live,

(3) who satisfies the desert which is far from water,

he is the very dew, as it descends from the sky.

(Day) 17.

Column I (right)

(1) The servant [Hote]p: 1 piece of textile

(2) $[\ldots]: 1$ piece of textile

(3) The servant $[\ldots]$ : 1 piece

(4) $[\ldots]: 1$ piece of textile

(5) $[\ldots]: 1$ piece of textile

(6) $[\ldots]: 1$ piece

(7) $[\ldots]: 1$ piece

(8) $[\ldots]$ : 1 piece

(9) [...illegible traces...]

Column II (left)

(1) $N w[\ldots]$-garments (?)

(2) The servant Seth: 2 pieces of cloth

(3) Ahmose son of Benu: 1 piece

(4) Ruiu: 2 pieces

(5) The assistant Djehuty: 1 piece

(6) Month 2 of Peret, day 3. The pure-priest Saiah: one piece of textile.

${ }^{29}$ Hagen, An Ancient Egyptian Literary Text in Context, 94.

${ }^{30}$ The use of the verb $\mathrm{km}$, whose meaning includes "create," "produce," but also "throw" and "hammer out metal" ( $W b$. V, 33.8-37.6), probably also alludes to the sun drying out the fields by "throwing" sunbeams on them. 
Hieratic and Philological Commentary

(I.1) The initial group is clearly the same as in (I.3) and (II.2), but the reading is problematic. I read $h m\{. t\}$, "servant," but the presence of the .t (feminine) is puzzling because the names appear to be masculine, as is particularly clear in the case of "Seth" in (II.2). ${ }^{31}$ Nonetheless the reading of the.$t$-ending seems certain; the scribe clearly distinguishes $\square$ from . It could theoretically be understood as a direct genitive "the servant-girl of NN," but in New Kingdom administrative texts this is, to my knowledge, always with the indirect genitive $n$, "of." 32 The least implausible option appears to me to interpret the feminine ending as a mistake, but although variants of $h \mathrm{~m} / \mathrm{hm} . t$ in administrative texts often omit the determinative altogether (as would also be the case here), or give the wrong determinative (a seated man for a seated woman, as is so common in hieratic texts), the insertion of a feminine ending by mistake is relatively rare. ${ }^{33}$ Alternatively, a reading 8 ( $(w$ d.t $t$, "command") is also possible palaeographically, but again the .t ending is curious and I can see no likely explanation for this use in a theophoric name: the only known names incorporating $w \underline{d}+$ divine name (cf. "Seth" in II.2) do not have a .t ending after $w \underline{d}$, and they invariably consist of the pattern $w \underline{d}+$ divine name $+{ }^{\top} n h=f / s$, " $\operatorname{God}(\operatorname{dess}) \mathrm{NN}$ has decreed his/her life." ${ }^{34}$ One would perhaps in any case expect a title to precede the personal name, as may be the case in II.5 and II.6. The reading of the personal name [ht $] p$ seems plausible, but only the final consonant and the determinative are preserved.

(II.1) This is a heading explaining the type of cloth being handed out, but only the first three signs of the line are legible to me. Perhaps the word is $n w . t$, "woven cloth" or "yarn," ${ }^{35}$ but the orthography seems unusual (I cannot reconcile the signs following $\bar{\Omega}_{c}$ with the expected ending.$t$ and the usual determinatives $\mathrm{\rho}$ or similar).

(II.5) I assume this line consists of a title plus name ("the assistant Djehuty"), rather than a personal name consisting of $w b 3$ + divine name ( $w b 3$ - $\underline{d} h w t y=$ "Assistant-of-Djehuty"); the latter pattern does not appear to be attested.

The administrative notes on the writing board are not in themselves very revealing. Lists of names followed by quantities of textile and cloth are common, and this one points to an individual involved in the management of resources, perhaps most likely in the context of an institution. The heading, which explains the type of textile being received (or less likely, handed out), is partly illegible, so it is difficult to say anything about their value, but although individual entries show relatively few items being circulated, the total sum $\left(15^{+}\right)$is not inconsiderable and makes it unlikely that the text relates to a domestic transaction. The entries are written on the "recto" of the board, where the student version of The Hymn to the Nile was copied, but the administrative notes themselves do not appear to be an exercise; the date inserted at the end of column II clearly relates to a different day of activity when another transaction involving a piece of textile took place, a detail that suggests that this is an actual record and not simply a didactic list of names to be copied for practice.

${ }^{31}$ I am unaware of any examples of women named "Seth," or of any female theophoric names with "Seth" as an element; cf. Ranke, PN I, 321-22.

${ }_{32}$ Examples with the indirect genitive include P. BNF 209, verso IIB: "the $h m . t$ Henutwadju of $(n)$ the charioteer Mery" (KRI I, 269.9); P. UC 32788, 2.2 ("P. Gurob K"): "the servant girl Takaru of (n) the citizeness Puy" (Gardiner, RAD, 29); and, less relevant in view of the omitted personal name, P. Leiden I 352, 1: "list of the things which the hm.t of $(n)$ the charioteer Pakharu took" (J. Černý, "Restitution of, and Penalty attaching to, Stolen Property in Ramesside Times," JEA 23 [1937], 186). There is a single example of what looks like a direct genitive construction ("slave-girl NN of NN") in P. Milan RAN E 0.9.40126 + 0.9.40128, recto $\mathrm{x}+7$, but as Demarée has argued, this should be interpreted differently; R. J. Demarée, "Ramesside Administrative Papyri in the Civiche Raccolte Archeologiche e Numismatiche di Milano," JEOL 42 (2010), 60.

${ }^{33}$ The omission of a feminine ending in $h m . t$ is also rare, but there is one example in P. Milan RAN E 0.9.40126 + 0.9.40128, recto $\mathrm{x}+7$; Demaree, "Ramesside Administrative Papyri," 57.

${ }^{34}$ Ranke, $P N$ I, 88.9-13 (attested for Amun, Ptah, and Mut).

${ }^{35}$ Wb. II, 217.3-7. 
More in line with the practice aspect of the literary text are the two words written in rather large letters on the right-hand side of the board, beneath the literary text: these read "birds" ( $3 p d w)$ and "people" $(r m \underline{t})$, two common words that can hardly have posed calligraphic problems for the experienced hand who copied the hymn above. Both words appear within the next ten verse-lines of The Hymn to the Nile ( $3 p d w$ in II.2 and $r m \underline{t}$ in II.8), but this may just be coincidence. There are three drawings on the recto of the board, all presumably by the same person who copied the literary text and the administrative notes on that side (the student). The largest, between the two columns of administrative entries is a detailed image of the head of a falcon with a sun-disc on top, and to the left of the second column there are two grasshoppers. The bottom one is only partly finished, and the hieratic text of line II.5 is superimposed on the drawing, showing that the text postdates the drawing.

\section{Writing Boards: Uses and Functions}

There has been a tendency amongst philologists in Egyptology to underestimate the complexity of material culture and the range of possible uses of any given medium employed in the transmission of texts. Ostraca containing literary compositions, for example, have often been labelled scribal exercises in an act of undifferentiated classification that obscures the variety of objects subsumed under this category. This interpretative model-which assigns the majority of surviving copies of Egyptian literature to an educational context-has occasionally been questioned ${ }^{36}$ and there are grounds for extending this questioning to writing boards. ${ }^{37}$ Surviving writing boards tend to be of either wood or limestone, and although they vary in size they are generally not much larger (or heavier) than could be comfortably carried and handled by an adult scribe. Writing tablets of limestone are generally modest in size, presumably partly because of their unwieldiness and weight, and are distinguished from limestone ostraca by having been shaped into a square or rectangular form, with one or both sides polished to facilitate writing. It has been suggested that wooden writing tablets generally conformed in size to contemporaneous papyrus formats, ${ }^{38}$ which in the New Kingdom would consist of heights of about forty-one to forty-three $\mathrm{cm}$ (a full-size roll, almost exclusively reserved for administrative and juridical documents), roughly twenty-one $\mathrm{cm}$ (a half-size roll, the most common format for literary manuscripts), and smaller rolls of approximately ten $\mathrm{cm}$ (a quarter-size roll). In addition to these categories there are a number of Eighteenth Dynasty literary manuscripts of about eighteen $\mathrm{cm}$ in height, which, if they correspond to half-size rolls, would suggest another common format of thirty-six $\mathrm{cm}$ for full-size rolls in circulation when the writing board Ashmolean 1948.91 was in use. ${ }^{39}$ However, with a height of fourteen $\mathrm{cm}$ it does not fall into either of these categories, and it is, to my knowledge, the smallest surviving New Kingdom writing tablet.

Wooden tablets consist of several thin boards attached to one another side by side in the form of a rectangle, which was then covered with a piece of linen and finally plastered with a layer of stucco (although from the Late period onwards linen and stucco seems not to have been used). Many have a hole drilled through the board near one of the short sides, presumably for a piece of string to be passed

${ }^{36}$ Hagen, An Ancient Egyptian Literary Text in Context, 84-100; Parkinson, Reading Ancient Egyptian Poetry, 174; G. Moers, Fingierte Welten in der ägyptischen Literatur des 2. Jahrtausends vor Christus: Grenzüberschreitung, Reisemotiv und Fiktionalität, PdÄ 19 (Leiden, 2001), 161-63.

${ }^{37}$ I know of few studies of writing tablets from ancient Egypt as material objects. The article by P. Vernus, "Schreibtafel," in LdÄ V, 703-9, remains the standard introduction, but cf. S. Quirke, "Archive," in A. Loprieno, ed., Ancient Egyptian Literature, PdÄ 10 (Leiden, 1996), 392-94; J.-L. de Cenival, "Les tablettes à écrire dans l’Égypte pharaonique," in E. Lalou, ed., Les tablettes à écrire de l'Antiquité à l'Époque Moderne: Actes du colloque international du Centre National de la Recherche Scientifique, Paris, Institut de France, 10-11 octobre 1990 (Paris, 1992), 35-40; Parkinson, Reading Ancient Egyptian Poetry, 173-74; Hagen, An Ancient Egyptian Literary Text in Context, 100-101.

${ }_{38}$ W. Hayes, "A Much-Copied Letter of the Early Middle Kingdom," JNES 7 (1948), 2, n. 9; cf. P. Vernus, "Schreibtafel," Ld̈̈ 5,704 .

39 J. Černý, Paper and Books in Ancient Egypt (London, 1952), 16-17. 


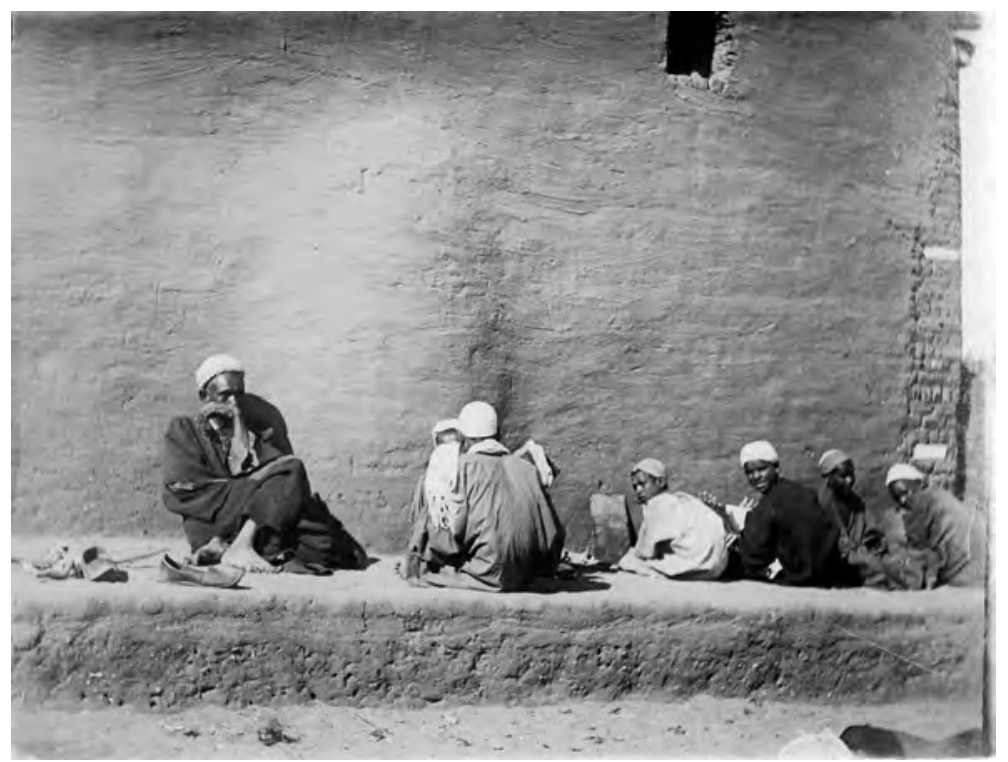

Fig. 5. Quranic school in Egypt (ca. 1898-1901), from the archive of Margaret Murray at University College London. Photograph courtesy of the Petrie Museum of Egyptian Archaeology.

through, which would enable the board to be attached to another object or to be suspended. Chronologically writing boards appear in the archaeological record already in the Old Kingdom, ${ }^{40}$ and they continue to be used throughout Egyptian history. ${ }^{41}$

The association of writing tablets with school and education is perhaps partly due to the historical experiences of nineteenth century Egyptologists and explorers in Egypt. These early archaeologists and travellers often remarked on the (supposed) striking similarities of life in rural Egypt at the time and that of their ancient predecessors, drawing parallels between modern and ancient agricultural practices, religious beliefs, and other areas of culture. They encountered writing tablets in use among the Quranic schools in the villages, with teachers sitting on the ground surrounded by students with writing tablets on their laps (fig. 5), and these scenes probably captured the imagination and appealed to the Enlightenment values of Western visitors; for Egyptologists the link with ancient Egypt may have seemed self-evident.

The famous ethnographer Edward William Lane (1801-1876) described these schools based on his visit to Cairo during the third decade of the nineteenth century in his Manners and Customs of the Modern Egyptians:

The lessons are generally written upon tablets of wood, painted white; and, when one lesson is learnt, the tablet is washed and another is written. They also practice writing on the same tablet. The schoolmaster and his pupils sit upon the ground, and each boy has his tablet in his hands ... ${ }^{42}$

Such ethnographic "parallels" are not unproblematic because of the specific cultural conditions of nineteenth century Egypt: heavily influenced by the Quranic tradition where students were trained in the language and writings of one particular book, their practices may not be directly comparable to

${ }^{40}$ E.g., E. Brovarski, "Two Old Kingdom Writing Boards from Giza," ASAE 71 (1987), 27-52; P. Posener-Kriéger, "Les tablettes en terre crue de Balat," in Lalou, Les tablettes à écrire de l'Antiquité à l'Époque Moderne, 41-52; cf. L. Pantalacci, "La documentation épistolaire du palais des gouverneurs à Balat-Ayn Asil," BIFAO 98 (1998), 303-15; idem, "Archivage et scribes dans l'oasis de Dakhla (Égypte) à la fin du IIIe millénaire," in L. Pantalacci, ed., La lettre d'archive; communication administrative et personelle dans l'antiquité proche-orientale et égyptienne, BiGen 32 (Cairo 2008), 141-51.

${ }^{41}$ R. Cribbiore, Writing, Teachers and Students in Graeco-Roman Egypt (Atlanta, 1996), 65-69.

${ }^{42}$ E. Lane, Manners and Customs of the Modern Egyptians (London, 1836), 86-87. 
pharaonic Egypt. ${ }^{43}$ In addition, the quality of the handwriting on ancient Egyptian tablets is frequently high, which has led some scholars to argue that they represent the teachers' master copies, rather than student exercises; J. W. Barns once remarked that "Writing boards from Pharaonic Egypt seem often to have been products of the schoolroom, being probably written by the schoolmaster rather than by pupils." ${ }^{\prime 4}$ The same argument is relevant to literary ostraca, ${ }^{45}$ but the absence of untrained hands proves little more than that the copyists were not beginners, and more advanced students could be responsible for the writing. ${ }^{46}$ Although writing boards are likely to have been used in the education of Egyptian scribes, their use was certainly not restricted to this context, nor where they primarily associated with education by the Egyptians themselves. There are few explicit sources where scribal equipment is discussed, but perhaps the most famous one is a passage from The Eulogy of Dead Authors from P. Chester Beatty IV (BM EA 10684) where the text uses various objects as metaphors for agents in the process of memorialization:

They made [the papyrus roll] their lector-priest, the wooden writing board their beloved son, wisdom instructions their tombs, the reed pen their child, the stone surface their wife. ${ }^{47}$

Here the writing materials of scribes are listed and described as the foundation both for their profession and for their reputation and continued existence in the afterlife: the writing board becomes a substitute for a "beloved son," the person who takes on responsibility for maintaining the cult of the deceased. This inclusion of writing boards in the basic equipment of a scribe-and the scribes in question are experienced professionals and famous authors, not students-is echoed on Middle and New Kingdom coffins where officials have writing boards depicted in the frieze of "everyday objects" as symbols of their literacy. ${ }^{48}$ Tellingly, late Old Kingdom and early Middle Kingdom tomb models of granaries show low-level scribes supervising the delivery and distribution of grain by keeping accounts on writing boards: these are made of wood, whitewashed and inscribed with hieratic signs. ${ }^{49}$ This area of use may in fact have been one of the most common for such boards, notwithstanding the fact that

${ }^{43}$ The single reference to a king having "sung" or "chanted" (hsy) writings with his companions (Merikare §E50-51) is often cited in the literature as evidence for a Quranic method of instruction, but there is no mention of a school context in the passage, and no other evidence for the "chanting" of texts in any ancient Egyptian didactic context.

${ }^{44}$ J. Barns, "A New Wisdom Text from a Writing-Board in Oxford," JEA 45 (1968), 72. Others have thought that writing boards were mostly copied by students: B. van de Walle, La transmission des textes littéraires égyptiens (Brussels, 1948), 10; H. Brunner, Altägyptische Erziehung (Wiesbaden, 1991), 73-74.

${ }^{45}$ E.g., J. Černý, review of B. van de Walle, La transmission des textes littéraires égyptiens (Brussels, 1948), in CdÉ 24 (1949), $68-71$.

${ }^{46}$ A. McDowell, "Teachers and Students at Deir el-Medina," in R. Demarée and A. Egberts, eds., Deir el-Medina in the Third Millennium AD: A Tribute to Jac. J. Janssen, EgUit 14 (Leiden, 2000), 217-33.

${ }^{47}$ A. Gardiner, Hieratic Papyri in the British Museum, Third Series (London, 1935), vol. II, pl. 18. Note the wood determinative of ' $n$, "writing tablet." The "stone surface" ( $s$ ' inr, lit. "back of the stone") could refer either to monumental inscriptions or to the use of limestone ostraca, compare O. DeM 10011 which describes itself with the words ky inr šrí, "another small stone"; P. Grandet, "ky inr šrí, «un autre petit caillou»: ostraca inédits de l'IFAO," in A. Dorn and T. Hofmann, eds., Living and Writing in Deir el-Medine, Aeg Helv 19 (Basel, 2006), 93, but in the context of memorialization the former is perhaps more likely, despite the general rarity of literary texts in monumental contexts.

${ }^{48}$ R. Parkinson, The Tale of the Eloquent Peasant: A Reader's Commentary, Lingua Aegyptia Studia Monographia 10 (Hamburg, 2012), 384 fig. 25; R. Parkinson and S. Quirke, Papyrus (London, 1995), 33; P. Lacau, CG 28079-28126, vol. I, 45-46, 178-79; vol. II, $13,23,44-45,57,61$.

${ }^{49}$ I am not aware of any detailed studies on the use of writing boards in tomb models, but for some examples see J. Breasted, Egyptian Servant Statues, Bollingen Series 13 (Washington DC, 1948), 12-15; Cenival, "Les tablettes à écrire dans l'Égypte pharaonique," 39-40. The model from the tomb of Meketre (MMA no. 20.3.11) shows four seated scribes, two with writing boards and two with papyrus rolls, indicating that both media were suitable in this context: Breasted, Egyptian Servant Statues, pl. 11b. 
a high proportion of surviving examples contain literary texts, not administrative accounts..$^{50}$ There are no texts describing the use and function of writing boards from pharaonic Egypt, and in those few cases where they are mentioned, the sources reveal little about these aspects. From the village of Deir el-Medina, the best-attested site for studies of literacy and written culture, a single fragmentary letter asks the recipient to

Hurry to the storehouse of Nefery and bring the papyri $(\underline{d} 3 m)$ which are there, along with the small scribal palette (gsti šri), and have them brought to me. And open (? 3w) the small chest which has been placed in the $[\ldots]$ of the gateway and get the documents, and attach them to the writing tablet $\left(\ulcorner n)[\ldots]\right.$ together with some $[\ldots]^{51}$

Here the writer appears to be a professional scribe asking for objects central to his work (compare the request for some rh.w, "lists," on the back of the same ostracon), where the basic supplies to be provided are papyrus, a palette with ink, and a writing board. The provision of both papyrus rolls and a writing board may imply that they had complimentary functions, perhaps with boards used for drafts and preliminary notes before a final version was composed on papyrus ${ }^{52} \mathrm{~A}$ similar function might be posited for writing boards with literary compositions-i.e., as being preliminary copies to be transferred to papyrus rolls, rather than exclusively as scribal exercises-but there is currently little evidence either way. Certainly the specific examples of literary texts on writing boards are closely matched by the known curriculum of New Kingdom scribal training, but the same texts are also attested in private libraries, showing that classical literature was transmitted in a variety of contexts and not only in school. Nonetheless, the Ashmolean writing board published here is most plausibly analyzed as belonging to a didactic context in view of the two parallel copies of the same passage from the same text. There are few other instances of this in the corpus of New Kingdom writing boards, but a recently published example from Thebes included the initial part of Kemit written once by a proficient hand (in two columns), and then twice (in four columns) by an untrained hand immediately to the right of the model text. ${ }^{53}$ The editor concluded that this corresponded to a teacher and an apprentice, providing a direct parallel to the way Ashmolean 1948.91 was used.

The Ashmolean writing board is palimpsest, but as so often it is difficult to estimate how long it would have been in use. Many writing boards show palimpsest traces, and the physical structure of the object-a wooden board with a washable and replaceable layer of stucco-implies repeated use, but beyond this there is little evidence on which to base estimates. Several of the surviving boards carry texts of more than ephemeral value (e.g., legal contracts, and a calendar of omens relating to the months of a year), but it is not clear whether these were meant to be kept in this way, whether they represent draft copies, or are simply scribal exercises..$^{54}$

\footnotetext{
${ }^{50}$ The state of preservation of many of the literary tablets suggests that they originate in tomb contexts, or at least come from necropolis areas: this is supported by the number of tablets found in the Theban necropolis; see H. Carter; Five Years' Exploration at Thebes (London, 1912), 36-37, 89-93. The proportion of literary vs. administrative texts would perhaps be different if one had a comparable survival rate for writing boards from settlement sites (where wood rarely survives because of the humid conditions).

${ }^{51}$ O. Petrie 62; Černý-Gardiner, Hier. Ostraca, I, pl. 73, no. 2; E. Wente, Letters from Ancient Egypt (Atlanta, GA, 1990), 165.

${ }_{52}$ This conclusion seems inescapable, but as has been pointed out in the comparable discussion about the role of administrative ostraca as "drafts" for papyrus documents, direct evidence is elusive. For a summary of the state of the debate with an overview of the relevant primary material, see K. Donker van Heel and B. Haring, Writing in a Workmen's Village: Scribal Practice in Ramesside Deir el-Medina, Eg Uit 16 (Leiden, 2003), 1-39.

${ }^{53}$ J. Galán, “An Apprentice's Board from Dra Abu el-Naga," JEA 93 (2007), 95-116. Another partial parallel to this practice is the fragmentary ostracon O. Turin 57054, J. López, Ostraca ieratici n. 57001-57092 (Milan, 1978), 34, pl. 29, where each column of Kemit was written twice, although it is not possible to allocate one or the other copy to a teacher or a student because of the fragmentary nature of the object. Compare also a writing board from tomb 37 at Deir el-Bahri, with the opening paragraph of Kemit on the recto and two lines of the same repeated on the verso; see Carter, Five Years' Exploration at Thebes, 91-92, pls. 77-78.

${ }_{54}$ The same problem applies to Greco-Roman writing boards, but here scholars have been more prepared to accept that some texts, such as contracts and wills, were meant to be kept for considerable periods of time: Cribiore, Writing, Teachers and Students in Graeco-Roman Egypt, 65.
} 
An unfortunate consequence of the tendency to assign, a priori, types of literary manuscripts like ostraca and writing tablets to a single social context-the more or less institutionalized education of Egyptian scribes-is that the literary texts found on these objects tend to be associated primarily with the same social context. Many literary texts written in Middle Egyptian ("Middle Kingdom classics") are thus seen as school texts in the New Kingdom, used to teach literacy and consumed-reluctantly by analogy with modern schools-by students who would rather be playing around, getting drunk, and generally misbehaving. ${ }^{55}$ It is incontestable that scribal training included the reading and copying of these texts, but it seems reductive to restrict the transmission to this context. To draw on an analogy advanced by Richard Parkinson, ${ }^{56}$ what impression would we have of Shakespeare if our only evidence for the modern transmission of his works stemmed from schools? Educational use of literary works lies at the heart of the construction of both literary canons and of social and professional identities, but in most cases it provides only one aspect of the existence and transmission of the works in question. The Hymn to the Nile is a case in point. In terms of manuscripts, there are some seventy ostraca, many of which are probably products of some kind of educational process; four writing tablets, which may also have been produced during scribal training: ${ }^{57}$ and five papyrus copies, for which the most plausible social context is private and/or institutional collections of manuscripts (see below). A tomb at Assiut also includes extracts of the text as part of an extensive range of literary graffiti left by visitors. ${ }^{58}$ Chronologically the manuscripts range from the early Eighteenth Dynasty to the second half of the Twentieth Dynasty, and although the date of composition is contested, ${ }^{59}$ by the Ramesside period the text was among the most frequently copied literary texts in circulation, only surpassed in number of manuscripts by The Instruction of Khety, The Instruction of Amenemhat, Kemit, and the "satirical letter" of P. Anastasi I. ${ }^{60}$

Although an exact archaeological context is not recorded for most of the ostraca, the majority must have come from the village of Deir el-Medina at Thebes. One exception is a potsherd ostracon, Ramesside in date, found by Petrie northeast of the mortuary temple of Tuthmose IV at Thebes during his excavations there in $1896 .{ }^{61}$ Many of the ostraca with The Hymn to the Nile in the IFAO were excavated by Bernard Bruyère during his work in and around Deir el-Medina in 1922-1951, and of these about one-third have recorded find-spots in the form of abbreviations written on the objects themselves when they were found (e.g., "GP 7.1.50" = Great Pit, 7 January 1950). Of the fourteen ostraca where this information is available, eight were found in the Great Pit to the northwest of the village. ${ }^{62}$ The pit itself appears to have been an abandoned attempt at digging a well, but at some point in the Ptolemaic period it was used to deposit material cleared from the surrounding area when the temple of Hathor was extended; several thousand ostraca were found here, but as this is very much a secondary context it says little about their original function or use.$^{63}$ Of the remaining ostraca with a provenance, one was found near tomb shaft no. 1112 in the necropolis to the west of the village,${ }^{64}$ another was found to the

${ }^{55}$ For these activities, and their attractiveness to scribal students, see the numerous passages in the Late-Egyptian Miscellanies dealing with the inattentive student: R. Caminos, LEM, 13, 83, 131, 182, 226-27, 231, 312, 319, 328, 377, 381-82, 436, 450.

${ }^{56}$ R. Parkinson, Poetry and Culture in Middle Kingdom Egypt: A Dark Side to Perfection (London, 2002), 236.

${ }^{57}$ This includes pieces of two limestone writing tablets (O. DeM 1757 and 1772) labelled as "ostraca" by van der Plas, L'Hymne á la crue du Nil, I, 7 ( = "IFAO X 3 " and "IFAO 11439"); for the reclassification see the catalogue by A. Gasse, Catalogue des ostraca hiératiques littéraires de Deir el-Médina, vol. IV (Cairo, 1990).

${ }^{58}$ See n. 25.

${ }^{59}$ See nn. 26-27.

${ }^{60}$ A. Gasse, "Les ostraca hiératiques littéraires de Deir el-Medina: Nouvelles orientations de la publication," in R. Demarée and A. Egberts, eds., Village Voices. Proceedings of the Symposium "Texts from Deir El-Medina and Their Interpretation," Leiden, May 31-June 1, 1991, CNWS Publications 13 (Leiden, 1992), 53.

${ }_{61}$ W. Petrie, Six Temples at Thebes (London, 1897), 9, 29, pl. 20, no. 7.

${ }^{62}$ O. DeM 1176, 1190, 1191, 1753, 1755, 1756, 1759 and 1770.

${ }^{63}$ On the ostraca found in the Great Pit, see B. Bruyère, Rapport sur les fouilles de Deir el Médineh (1948-1951) (Cairo, 1953), 60-64. The dating of the clearance is based on Ptolemaic ostraca found mixed up with the New Kingdom material (pp. 28-29).

${ }^{64}$ O. DeM 1760 (= IFAO inv. no. 1643). 


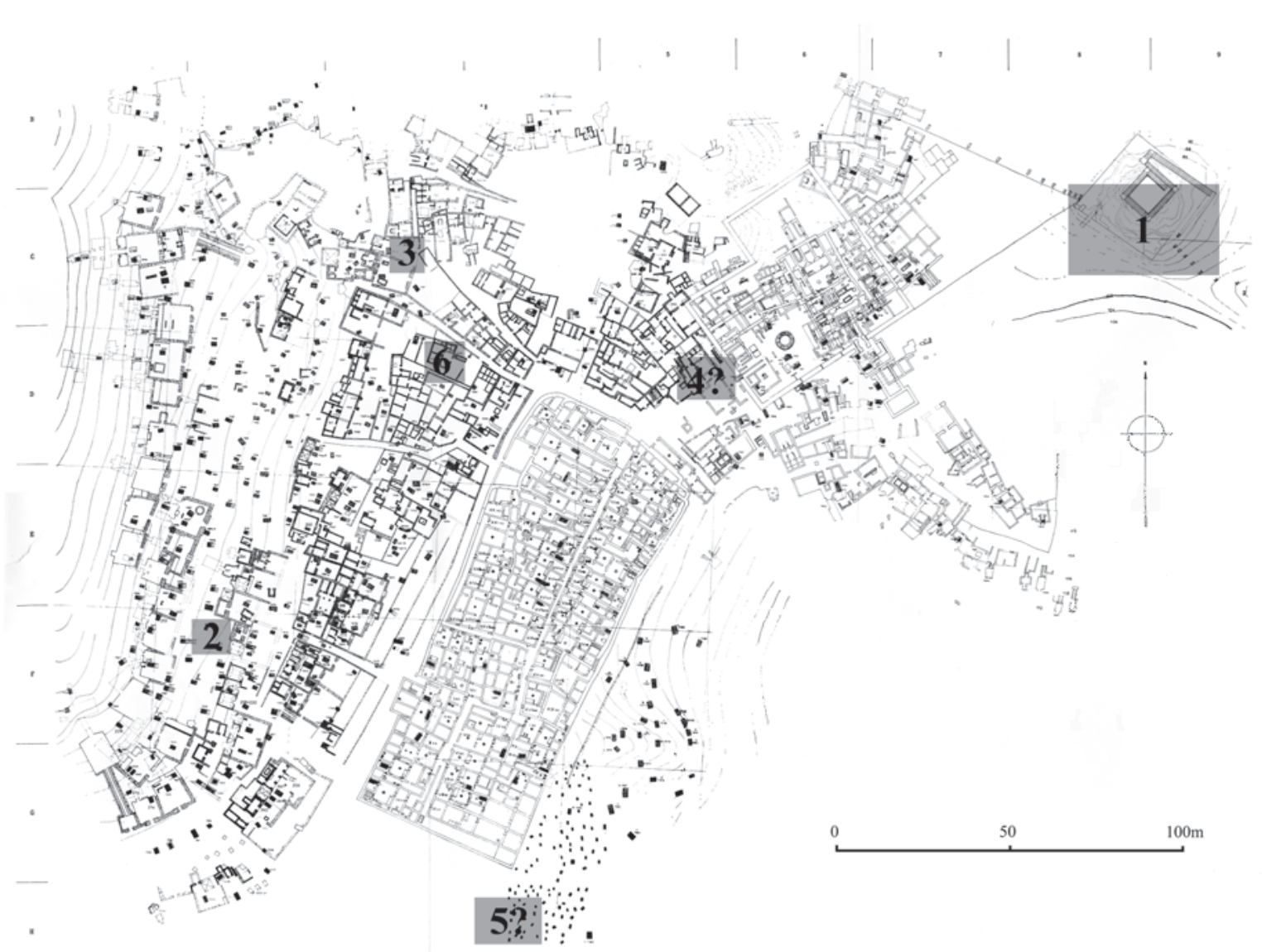

Fig. 6. Map of the village of Deir el-Medina (after G. Castel, Deir el-Médineh 1970, FIFAO 12.1 [Cairo, 1980], plan no. 1; courtesy of the IFAO, Cairo) with the findspots of ostraca with The Hymn to the Nile indicated. All locations are approximate; exact coordinates cannot be extracted from the excavation records: (1) the great pit [8 ostraca], (2) near shaft 1112 [1 ostracon], (3) near TT290 [1 ostracon], (4) south of Hathor temple [1 ostracon], (5) in mounds of debris south of village [2 ostraca], and (6) near chapels 1275 and 1276 [1 ostracon].

northwest by Theban Tomb no. $290,{ }^{65}$ a third was found just south of the Hathor temple,$^{66}$ two more were found in the mounds of debris to the south of the village, ${ }^{67}$ and finally five fragments of a single pot where found near the private chapels (nos. 1275 and 1276) to the northwest ${ }^{68}$ all are marked on the accompanying map (fig. 6). ${ }^{69}$

Few of these archaeological contexts are revealing, but they show a distribution of manuscripts whose lack of concentration is perhaps itself noteworthy; The Hymn to the Nile is also absent among the literary ostraca marked as found in the "K2" area to the northwest of the village which Gasse interpreted as a school. ${ }^{70} \mathrm{~A}$ final group of ostraca with The Hymn to the Nile thay have a recorded provenance are the

${ }^{65}$ O. DeM 1752 (= IFAO inv. no. 10450).

${ }^{66}$ O. DeM 1765 (= van der Plas" "oIFAO(x-1)").

${ }_{67}$ O. DeM 1027 and 1761 (= IFAO inv. no. 6162; mislabelled by van der Plas, L'Hymne á la crue du Nil, vol. I, 7, as "oIFAO (9162)").

${ }^{68}$ O. DeM 1051-1054; 1094.

${ }^{69}$ The remaining ostracon (O. DeM 1774) is marked "cour 116"; I do not know to which courtyard this refers (Theban Tomb 116, which might have been a possibility, is not part of the Deir el-Medina necropolis).

70 A. Gasse, "Le K2, un cas d'école?" in Demarée and Egberts, eds., Deir el-Medina in the Third Millennium AD, 109-20. How- 
so-called Ramesseum ostraca published by Spiegelberg. Of these four, two (nos. 92 and 96) may have been found "in the brick chambers built around three sides of the Ramesseum ... in six long chambers on the N. W. of the building," whereas the final two (nos. 90 and 100) were found "in a slightly raised part of the ruins in the south east corner."11 The latter locality was, like the "K2" area at Deir el-Medina, interpreted as a school based on the concentration of literary texts among the ostraca (most of which are potsherds rather limestone flakes). Recent excavations at the Ramesseum have yielded more ostraca from the same area, and among classics like The Instruction of Khety, The Instruction of Amenemhat, and Kemit, several ostraca with The Hymn to the Nile were discovered. The find itself remains unpublished, but the excavator interpreted this as a temple school or "House of Life," again largely based on the concentration of literary ostraca in one area of the site..$^{72}$

The papyrus manuscripts, though few in number, sometimes have an archaeological provenance, if only in the widest sense. P. Chester Beatty V (= BM EA 10685), which has a copy of The Hymn to the Nile along with model letters and passages from the Late-Egyptian Miscellanies on the front, and model letters and magical texts against scorpions and headaches on the back, belonged to the private library of a scribe of Deir el-Medina, Qenherkhepshef, and his family. A further papyrus manuscript with the hymn is preserved in Turin, and this may also be from Deir el-Medina; ${ }^{73}$ it also contains The Instruction of a Man for His Son, and has a calendar of lucky and unlucky days on the back. ${ }^{74}$ P. Anastasi VII (= BM EA 10222) appears to have come from Saqqara; this contains the hymn as well as The Instruction of Khety on the front, with various administrative notes on the back..$^{75}$ Finally, an unpublished fragment (P. UC 32803) with the beginning lines of the composition was found at Kom Medinet Gurob at the entrance to the Fayum oasis during Petrie's excavation of a palace site there, although the exact findspot within the site was not recorded. The archaeology of the manuscripts, even if the exact details of their discovery remain unknown, shows that the composition was transmitted throughout the Nile valley, from Saqqara in the north to Thebes in the south, as well as in the Fayum area. This is unlikely to represent the limits of the dissemination of the text, however, and-the vagaries of manuscript survival notwithstanding-further copies will undoubtedly come to light at other sites. ${ }^{76}$

The composition presents itself as a song or hymn to the Nile flood as personified by Hapy, and as such concerns itself with the most central feature of the Egyptian agricultural year, the inundation. Its vivid description of the importance of the river, its power over life and death, and the exposition of the inundation as the basis for both wealth and poverty, retains some of its poetic resonance even in modern translations, but we have no contemporary metatextual commentaries, and few clues as to its social importance or role, except for the manuscripts and a few text-internal references. One the one hand

ever, an ostracon with The Hymn to the Nile was found near TT290 (see fig. 6), so not far from the K2 area which lies immediately to the north of this.

${ }^{71}$ W. Spiegelberg, Hieratic Ostraka and Papyri Found by J. E. Quibell in the Ramesseum, 1895-6 (London, 1898), 1-2.

72 C. Leblanc, "L'école du temple (ât-sebait) et le per-ankh (maison de vie). À propos de récentes découvertes effectuées dans le contexte du Ramesseum," Memnonia 15 (2004), 96.

${ }^{73}$ Although neither has a recorded archaeological context, most New Kingdom literary texts in Turin seem to be from Thebes (and Deir el-Medina in particular): A. Roccati, "Les papyrus de Turin," BSFE 99 (1984), 9-27, esp. 18-21; cf. D. Valbelle, Les ouvriers de la tombe: Deir el-Médineh à l'époque ramesside (Cairo, 1985), 338-39.

${ }^{74}$ On P. Turin Cat. $1968+1890+1878$ and CGT 54016, see the brief remarks of van der Plas, L'Hymne à la crue du Nil, vol. I, 4, with bibliography; add now H.-W. Fischer-Elfert, Die Lehre eines Mannes für seinen Sohn (Wiesbaden, 1999), vol. 2, and S. Demichelis, "Papiri calendariali del Museo Egizio di Torino," Vicino Oriente 11 (1998), 103-12.

${ }^{75}$ Quirke, "Archive," 391.

${ }^{76}$ Compare the recently discovered ostraca with The Instruction of Amenemhat (which was frequently transmitted together with The Instruction of Khety and The Hymn to the Nile) from Amara West in the Sudan, more than $400 \mathrm{~km}$ south of Elephantine; R. Parkinson and N. Spencer, "The Teaching of Amenemhat at Amara West," Egyptian Archaeology 35 (2009), 25-28. For a recently identified example, without a recorded archaeological context but probably from Deir el-Medina, see O. E.71.1926, published in F. Hagen, New Kingdom Ostraca from the Fitzwilliam Museum, Cambridge, CHANE 46 (Leiden, 2011), 9-10, pl. 6. The hieratic ostraca from the mortuary temple of Merenptah at Thebes also include a single copy of the text; these are being prepared for publication by Matthias Müller (Basel), who very kindly allowed me to see a preliminary draft of the catalogue entry for this object (no. 11). 
the text labels itself as an "adoration" or "hymn" $(d w 3 w)$ to Hapy, thus associating itself on a formal level with a genre of texts addressed to various gods. Such "hymns" tend to be interpreted as belonging either to an official cultic context-where they might be sung or recited on a semiregular basis as part of rituals performed by priests-or to a more domestic religious context where they might be sung or recited as part of personal worship. ${ }^{77}$ The former seems less plausible in view of the lack of an established cult of Hapy in Middle and New Kingdom Egypt: there are no priests of Hapy, no temples dedicated to him have been found, and no divine cult statues have been identified. ${ }^{78}$ If the "worship" of Hapy should be sought in less institutional contexts, for example as part of public celebrations surrounding the annual flooding of the Nile, a broader range of social groups (participants and audience) involved in the performance and reception of The Hymn to the Nile should perhaps be envisaged, although the exact nature of these celebrations remains largely unknown. The text itself refers to Hapy as "one to whom his followers sing $(h s)$," perhaps alluding to compositions sung at such occasions. Assuming that the line is not a later interpolation, it suggests that the practice of singing songs to the Nile flood pre-dates the composition date of the text, and although The Hymn to the Nile became the most frequently copied of these songs-judging from the number of surviving manuscripts-it was certainly not the only one. ${ }^{79}$ The Hymn to the Nile itself includes several sections describing the festivities surrounding the beginning of the flood:

One plays the harp for you, and sing with (clapping) hands, while youngsters and children applaud $(\mathrm{nhm})$, and a joyful procession (wpwt) is arranged. (§XI.1-4)

Arise, Hapy, as one offers to you, as one slaughters cattle for you, as one makes a great offering for you, as one fattens fowl for you, as one captures the lions of the desert for you, as one repays you for your goodness.

$(\S X I I I .1-7)^{80}$

The scenes conjured up by the text, of a public feast accompanied by music, singing, clapping, and dancing, of processions and offerings of food, is perhaps the closest we get to a contemporary description of the celebrations at which The Hymn to the Nile might have been sung. This would probably

77 Van der Plas, "Dating the Hymn to Hapi," 472-75 (see note 26 above), argues forcefully for a cultic use of the text.

78 Van der Plas, L'hymne à la crue du Nil, vol. I, 179. The variant text of §VI.1-2 in P. Anastasi VII ("He [i.e., Hapy] has no shrines, no portions, no service") is perhaps relevant here, if the translation by M. Lichtheim, Ancient Egyptian Literature, vol. 1 (Berkeley, 1973), 207, is correct. Unfortunately the key word "shrine" ( $\left.n^{`} y t\right)$ appears to be otherwise unknown (Wb. II, 207.16, unless this is a variant of $n 3 y t$, "weaving workshop"; Wb. II, 200.2-4), and the word "portions" (tnw) can also mean "number" ( $n n$ $t n w=f$, "his number does not exist," i.e., he is immeasurable).

${ }^{79}$ There are several other songs to Hapy from the New Kingdom, most of which are attested on ostraca from Deir el-Medina (O. DeM 1105 and 1675; O. Gardiner 28). Where titles are preserved these are labelled as "hymns" or "adorations" (dw3w) to Hapy, and survive in single copies; H.-W. Fischer-Elfert, Literarische Ostraka der Ramessidenzeit in Übersetzung (Wiesbaden, 1986), 29-62; S. Bojowald, "Einige Bemerkungen zu O. DeM 1675 vs. 13/14," GM 195 (2003), 13-16. Two further hymns translated by Fischer-Elfert may also be related to Hapy; one (O. Gardiner 308) is a hymn to an anonymous creator-god, in parts reminiscent of The Hymn to the Nile in its imagery (but also of other religious compositions), the other (O. Gardiner 301) is a hymn to Nun, "the primeval waters," with which the Nile flood was frequently associated; Fischer-Elfert, Literarische Ostraka der Ramessidenzeit in Übersetzung, 13-22. An unpublished ostracon ("11677”) with another hymn was signalled by D. van der Plas, "Nile Hymns," in D. Redford, ed., The Oxford Encyclopedia of Ancient Egypt (Oxford, 2001), vol. 2, 144. The Gebel Silsileh stelae (see n. 81 below) include passages that might also be called hymnic in style.

${ }^{80}$ The translations are my own and are a deliberately loose rendering of the original. For a philological commentary and a more literal translation, see van der Plas, L'hymne à la crue du Nil, vol. I, 138-39, 146-49. 
have involved all levels of society, up to and including the king; certainly, several kings of the Ramesside period set up stelae in honor of Hapy near Gebel Silsileh, a place considered "holy" (Dsr) to that god. ${ }^{81}$ These rock-cut stelae, left by three consecutive kings of the Ninetheenth Dynasty (Seti I, Ramesses II and Merenptah), as well as Ramesses III some thirty-five years later, are virtually identical in terms their inscriptions (with the exception of the titularies and dates), and essentially provide details about the offerings that are to be provided for Hapy "twice a year, in the neighborhood of the pure waters of Silsileh, the holy place." The timing of the offerings (1 Akhet 15 and 3 Shomu 15) coincided with the lowest point of the Nile and the beginning of the inundation season, and were intended to ensure that there would not be a lack of water, rather than celebrating the arrival of Hapy as such. ${ }^{82}$ The offerings were to be provided from the storehouses of the temple of Amun-Re at Karnak, and were divided into two groups; one consisting of a young calf and three geese, the other of considerable amounts of meat, bread (some baked to resemble crocodiles and hippos), cakes, milk, honey, fruit, vegetables, wood, minerals, incense, wine, and assorted "images" of various materials, perhaps depicting Hapy himself. The offerings were to be made "on that day of throwing the book of Hapy" (hrw pf $n$ xAa mDA.t Hapy), a phrase that recurs in a similar context in the great Harris papyrus (BM EA 9999, 37b, 16; 54a, 2) where the book is clearly a papyrus roll containing a list of the offerings. ${ }^{83}$ It has been suggested that the roll was thrown into the Nile as part of the ritual, but as R. A. Caminos has pointed out, this is never stated explicitly in the ancient sources. ${ }^{84}$ The Harris papyrus provides similar lists of offerings under two separate headings with one relating to Memphis and the other to Heliopolis; state-sponsored offering rituals to the Nile flood are thus attested over a wide geographical area, incorporating major cult centers as well as more provincial sites like Gebel Silsileh.

\section{Conclusions}

The Ashmolean writing board contains one of the earliest extant copies of The Hymn to the Nile, from the early Eighteenth Dynasty, and is a rare example of an object containing both a master's copy and a student's copy of the same text. As such it is important both for the question of the date of the text itself, and for investigating the role of literature in training practices. It also, in this case, provided a starting point for a contextualized analysis of this text, which looked at the possible uses and functions of the text, its audience, reception, and transmission in New Kingdom Egypt. One of the challenges facing philologists today is to move beyond a purely text-critical approach to Egyptian manuscripts where, once a manuscript has been harvested for textual variants and incorporated into synoptic editions, the object itself is left behind. This is counterproductive because there are invariably aspects of the material culture of a manuscript that can illuminate the social context of the object itself, and through this the social context of the composition it contains. My argument here has been that it is worthwhile to conduct such "close readings" of the material objects, and to confront established interpretations of the relevant category to which they belong-in this case the simplistic interpretation of writing tablets

${ }^{81}$ For the text of the stelae see KRI I, 84-96 (esp. 89.6 and 90.5 for the designation of Silsileh as "holy"); cf. P. Barguet, "Les stèles du Nil au Gebel Silsileh," BIFAO 50 (1952), 49-64. Despite the lack of a settlement of any size here, high officials of the Eighteenth Dynasty also set up several shrines or cenotaphs nearby, high up in the rock cliffs, and these would only have been accessible during the Nile flood; it seems probable that there was some connection with the worship of Hapy. The sandstone cliffs close to the water's edge funnels the Nile between fairly narrow walls of stone during the inundation, and this would have created an impressive visual effect; as R. Caminos and T. G. H. James remarked, "At Silsilah, when the Nile was in flood, a pious person might well feel that he was closer to the divine power than in any other place.... The existence of the quarries may only incidentally have been a reason for the choice of Silsilah for such monuments," Gebel es-Silsilah, vol. I: The Shrines (London, 1963), 9-10.

${ }_{82}$ The dates in the headings of the royal decrees relate to when they were issued, and not the dates of the festivities, as noted by Jac. Janssen, “The Day the Inundation Began,” JNES 46 (1987), 136.

${ }^{83}$ P. Grandet, Le Papyrus Harris I, BdÉ 109 (Cairo, 1999), vol. II, 274, 297. The same ritual is also mentioned in a list of religious festivals from the temple of Esna almost a thousand years later; S. Sauneron, Esna V: Les fêtes religieuses d'Esna (Cairo, 1962), 55, n. 1.

${ }^{84}$ R. Caminos, "Nilopfer," in $L d \ddot{A} 4$, 499, n. 4. 
as stemming exclusively from school and scribal training-all of which is central to the process of reconstructing the social context of Egyptian literature.

By looking at the archaeological context of the different manuscripts one can get an impression of the transmission and use of The Hymn to the Nile; copies have been found throughout the Nile Valley, indicating a text with a wide area of circulation, and with a transmission period spanning several hundred years. Although there can be no doubt that The Hymn to the Nile figured prominently in the scribal curriculum of the New Kingdom, as evidenced by many of the ostraca, this is unlikely to have been the only setting in which it was read and copied. Papyrus copies in collections of manuscripts in private hands hint at a different sphere of consumption, but reconstructing a wider social context for the text is difficult due to the paucity of direct evidence. Presumably The Hymn to the Nile featured as part of the repertoire of songs sung to welcome the annual flood, but we have little to go on except for the text of the hymn itself, as well as other compositions from the same genre.

University of Copenhagen

\section{Addendum}

As this article was going to print, Nadine Moeller brought to my attention that among the ostraca recently found by her excavations at Tell Edfu there is another copy of The Hymn to the Nile. This ostracon (TEO 135), which contains the initial lines of the poem, was found in a large fill layer from one of the silos. The stratigraphy provides an archaeological context in the late Second Intermediate Period or very early Eighteenth Dynasty. The hieratic hand looks earlier than the Ashmolean board to me, so that it could well be the very earliest copy of the text yet found. It will be published, along with the administrative texts, by Kathryn Bandy of the University of Chicago. I am grateful to both colleagues for sharing the information and for discussing the provenance with me. 